University for Business and Technology in Kosovo

UBT Knowledge Center

UBT International Conference

2016 UBT International Conference

Oct 28th, 9:00 AM - Oct 30th, 5:00 PM

\title{
The Neutralization of Water Polution
}

\author{
Afrim Osmani \\ University for Business and Technology, afrim.osmani@ubt-uni.net
}

Follow this and additional works at: https://knowledgecenter.ubt-uni.net/conference

Part of the Engineering Commons, and the Physical Sciences and Mathematics Commons

\section{Recommended Citation}

Osmani, Afrim, "The Neutralization of Water Polution" (2016). UBT International Conference. 44.

https://knowledgecenter.ubt-uni.net/conference/2016/all-events/44

This Event is brought to you for free and open access by the Publication and Journals at UBT Knowledge Center. It has been accepted for inclusion in UBT International Conference by an authorized administrator of UBT Knowledge Center. For more information, please contact knowledge.center@ubt-uni.net. 
Book of Proceedings

International Conference on Mechatronics, Sciences in Energy Efficiency Engineering,

System Engineering and Robotics

\title{
The Neutralization of Water Polution
}

\author{
Afrim Osmani \\ UBT - Higher Education Institution, Lagjja Kalabria, 10000 p.n., \\ Prishtine, Kosovo \\ afrim.osmani@ubt-uni.net
}

\begin{abstract}
One of the biggest sources of pollution land and water are industrial waste waters.
At section of zinc industry in complex Trepca during the process of zink production acquire(are gained or obtained) wastewater where their negative impact is wider extent of contamination of land with which it comes in contact and in this case comes to the accumulation ions of heavy metals, surfacewater and then mixing with groundwater and pollution.

Directly with vulnerable is Sitnica river, in which contaminated water flows from the industrial unit for the production of $\mathrm{Zn}$, which flows into the Ibar river, which still flows into the Morava river in Serbia, thus presents a problem internationally.

The objective of the paper is concerned with the characteristics of industrial wastewater from the section of zinc in Trepca complex and their impact on water pollution around.

Are made quantitative and qualitative analyzes of samples of polluted water before and after the production process and is found high content of ions of heavy metals such as: $\mathrm{Pb}, \mathrm{Zn}, \mathrm{Cu}, \mathrm{Fe}, \mathrm{Cd}, \mathrm{Bi}$, $\mathrm{Ni}, \mathrm{Co}, \mathrm{Sb}, \mathrm{Sn}$, etc., and which exceed the values of MLD, provided by international legislative rules. Neutralization is made of industrial wastewater based on the $\mathrm{pH}$ value and concluded that the water is rich belongs to the category of IV water according to legal regulations for water.
\end{abstract}

Keywords: Neutralization, wastewater, contamination

\section{Entry}

Natural water is clean and basic and indispensable element for human life, plant and animals, so is the principle that all the inhabitants of the planet to care for the exploitation and protection of his right.

Population growth and rapid development of society in terms of technological industry and has lead to enormous exploitation of water resources as well as to excessive pollution of water (surface-and groundwater).

In recent decades, as locally and internationaly importance that special attention is paid to cleaning of industrial wastewater, in order to improve the level of water pollution.

A special emphasis is paid of: equipment, automation for the processing of wastewater with dosing reagent then high frequency of cleaning of metal ions with slaked limes, eligibility and elements present in the molten.

Water that is used in technological processes for the production of metal is actually contaminated water. The degree of contamination depends on the amount of waste that water contains. 
The Neutralization of Water Polution

While matter pollutants coming from industrial units, then it comes to industrial wastewater, while if they come from more than urban households having then it comes to municipal wastewater. So that these waters back in kind and used again they must undergo purification process, which is performed through mechanical methods, chemical and biological.

Chemical methods for purification of water mean water purification process, which is based on chemical reactions and physico-chemical phenomena. Chemical process for the purification of water is very costly, but for cleaning the impurities present in the water some chemical process is no alternative.

As a base chemical cleaning process of polluted water from some solvable matteries is: With chemical precipitation with ion exchange,gas blow oxidation and adsorption.

Industrial wastewater resulting from the different sections of the technological processes, but as their common characteristic is the high degree of toxicity receptors. The toxicity of these waste water is expressed by the degree of acidity and alkaline in the presence of a number of heavy metals, phenols, mineral oils and detergents, and in

\section{Technological process for the processing of industrial waste water}

Equipment for processing of industrial wastewater with neutralization process are intended for: receiving, neutralization and water purification, as well as filtering waste from contaminated water. Liquid waste which come from different sections collected in the basin 93 VE 93 16. One of pumps PP $18 \mathrm{~A} / \mathrm{B}$ made pumping in tank for neutralization in $93 \mathrm{VE} 18 \mathrm{~A} / \mathrm{B}$ that are located at cascade mood Slaked lime obtained from the processing of qiuck lime, which is transported through track and is stored in the bunker $93 \mathrm{BN} 10$. And slaked lime through ekstraktor $93 \mathrm{CV} \mathrm{11,} \mathrm{with} \mathrm{the} \mathrm{help} \mathrm{of}$ pneumatic valve, drawn and with spiral transporters $93 \mathrm{CV} 12$ forwards so booked for the preparation milk lime, where the reservoir is equipped with agitator $93 \mathrm{VE} 13$.

Measurer level, through the contactor with the upper and lower part, made the opening for the supply of lime and water when the lower level is reached and interrupt when the upper level is reached. Preparing thus becomes the lime with $10 \% \mathrm{Ca}(\mathrm{OH}) 2$. Specific weight of hydrated lime optimal adjusted based on experience.

The injection of lime made in two reservoirs, so that neutralization is done in stages, at $\mathrm{pH} 4-5$ in the reservoir $93 \mathrm{VE} 18$ and at $\mathrm{pH}=7$ in the reservoir $93 \mathrm{VE} 18 \mathrm{~B}$.

The third reservoir for flotation $93 \mathrm{~V} 20$ also is placed in cascade mode compared with the reservoir93VE18A/B.

Reagent for flokulim, FeClSO4, preparation mechanically with $10 \%$ to rezervoir 93 VE 22 andwith the aid pump for dosing PP $9324 \mathrm{~A} / \mathrm{B}$, the flow of which is regulated mechanically and sent to the reservoir 93 VE 20.

In cases where the $\mathrm{pH}$ value measured in the reservoir $93 \mathrm{~V} 18 \mathrm{~B}$ is low, then through a tube contaminated water turn in the basin 93 VE 16 through automatic valve which is located at the outlet of the reservoir $93 \mathrm{VE} 20$.

The solution whose is added flocculant(layer) through gravity sent to precipitation $93 \mathrm{TN} 29$. We added at supplier cylinder of precipitator polyelectrolyte which serves as a catalyst for precepitation. This polyelectrolyte preparation mechanically by $0.1 \%$ in the reservoir 93 VE 26 and injected through a dosing pumpe PP $9328 \mathrm{~A} / \mathrm{B}$, where the flow is regulated mechanically.

The clean neutralized solution flow from precipitator with gravitation and goes to the river. 
Book of Proceedings

International Conference on Mechatronics, Sciences in Energy Efficiency Engineering, System Engineering and Robotics

Precipitate collected at the end of precipator passes through the reservoir to homogenise 93 VE 31, and with the help of a membrane pumpe PP 9332 A / B pumped into the filtration equipment. Obtained precipitate undergoing processing, while filtrate goes into the river. 
The Neutralization of Water Polution

In Fig.1. The following will be presented technological scheme of industrial waste water processing (section 093).

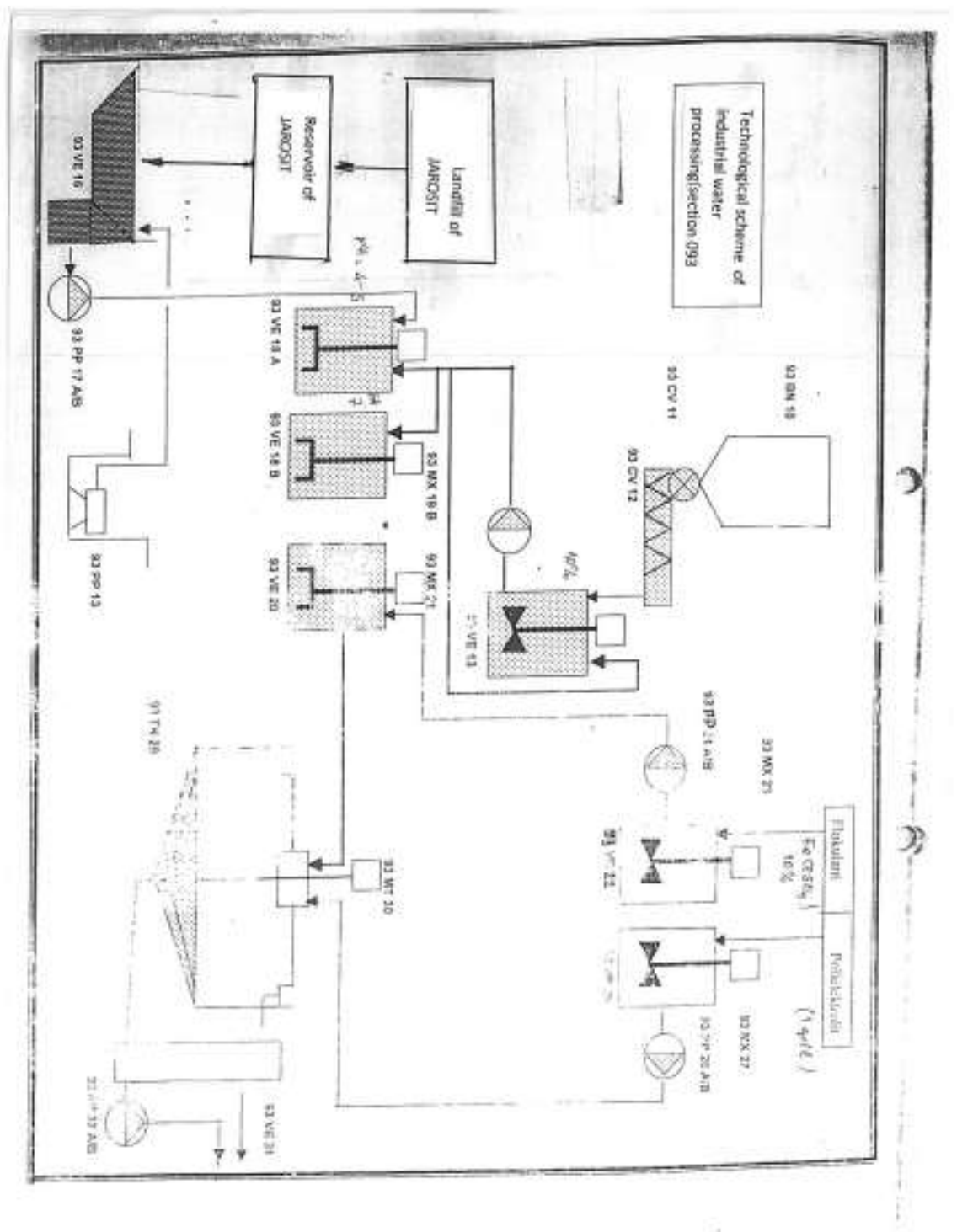


Book of Proceedings

International Conference on Mechatronics, Sciences in Energy Efficiency Engineering,

System Engineering and Robotics

\section{Experimental Part}

The degree of efficiency during precipitation of heavy metals depending on the $\mathrm{pH}$ value of industrial waste water processing of zinc metallurgy

Practically is confirmed that the process of cleaning wastewater with slaked lime in the form suspension is economical. The reason of process to processing with slaked lime based in the fact that most metal ions precipited in the form of hydroxides, where the rate of precipitation, where them precipitation scale depends how like the homogenity, concentration of metal ions and the amount of dosed of lime that depends on the $\mathrm{pH}$ value. The process of neutralization of acidic wastewater is carried out in $\mathrm{pH}=$ 7.5-8.5, which in this case comes to heavy metal precipitation.

As a result of the neutralization process and hydrolysis acidic wastewater that comes to precipitation of heavy metals in the form of hydroxide, but as a result of the presence of calcium carbonate comes even to the formation of carbonate. With the introduction of chemical reagent made destabilization of colloids as a result of this we have the process of coagulation. Giving the reagents, which ions react with colloids comes to the elimination of electrostatic forces in colloids.

As a result of the coagulation process and the formation of more floske, to which precipitate. With this reach the precipitation of heavy metals from wastewater, regardless of $\mathrm{pH}$ values for some oxides, such as are given in tab.1.following: :

Tab.1.precipitationof $\mathrm{pH}$ values of some heavy metal hydroxides are as follows:

\begin{tabular}{|l|l|}
\hline Hydroxide & pH value \\
\hline $\mathrm{Pb}(\mathrm{OH})_{2}$ & 6 \\
\hline $\mathrm{Zn}(\mathrm{OH})_{2}$ & 6 \\
\hline $\mathrm{Mg}(\mathrm{OH})_{2}$ & 11 \\
\hline $\mathrm{AgOH}$ & 9 \\
\hline $\mathrm{Hg}(\mathrm{OH})_{2}$ & $7-8$ \\
\hline $\mathrm{Ca}(\mathrm{OH})_{2}$ & $7-8$ \\
\hline $\mathrm{Cu}(\mathrm{OH})_{2}$ & 6 \\
\hline $\mathrm{Cd}(\mathrm{OH})_{2}$ & $7-8$ \\
\hline $\mathrm{Zr}(\mathrm{OH})_{2}$ & 4 \\
\hline $\mathrm{Fe}(\mathrm{OH})_{3}$ & $2-3$ \\
\hline $\mathrm{Ge}(\mathrm{OH})_{4}$ & $2-3$ \\
\hline $\mathrm{Ti}(\mathrm{OH})_{3}$ & 4 \\
\hline $\mathrm{Ni}(\mathrm{OH})_{2}$ & $7-8$ \\
\hline $\mathrm{Pb}(\mathrm{OH})_{4}$ & $7-8$ \\
\hline $\mathrm{Bi}(\mathrm{OH})_{3}$ & 6 \\
\hline $\mathrm{Al}(\mathrm{OH})_{3}$ & 4 \\
\hline
\end{tabular}


The Neutralization of Water Polution

Also process wastewater processing is done with the help of flocculant and polyelectrolyte.

FeClSO4 is used as an electrolyte, which serves to create greater floske. Thus the reaction between $\mathrm{H} 2 \mathrm{SO}$ and $\mathrm{Ca}(\mathrm{OH}) 2$ occurs the formation of $\mathrm{CaSO} 4$, which is characterized by product solubility lower, which runs the precipitate and detached attracts the heavy metals in the form of hydroxide, as follow reactions:

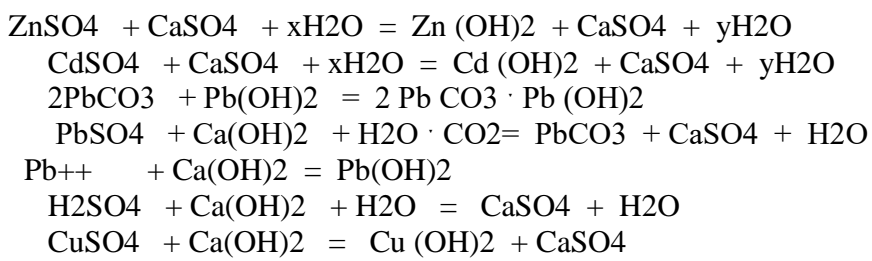

\section{Chemical composition analysis}

Verification scale of precipitation of heavy metals and neutralization complete with chalk erased depending on the $\mathrm{pH}$ is made independently of content, $\mathrm{Pb}, \mathrm{Zn}, \mathrm{Cu}$ and $\mathrm{Cd}$ and that both before and after cleaning the wastewater industrial.

It also has become the research content of heavy metals even in certain $\mathrm{pH}$ values of 9 to 10.5 in reservoirs for wastewater neutralization.

Analysis for heavy metals are carried out polarigrafike method and results are given in the table.Wastewater samples were taken every 2 hours and it shaped composite.

Tab. 2. Sample no. 1 .

\begin{tabular}{|l|l|l|l|l|l|}
\hline Sample 1 (mg /l) & $\mathrm{pH}$ & $\mathrm{Pb}$ & $\mathrm{Zn}$ & $\mathrm{Cu}$ & $\mathrm{Cd}$ \\
\hline Wastewater & 2.5 & 3.8 & 985 & 1.6 & 2.7 \\
\hline Before cleaning & 8 & 2.3 & 350 & 1.1 & 1.3 \\
\hline After cleaning & 9 & 1.1 & 130 & 0.23 & 0.3 \\
\hline After cleaning & 10.5 & 0.45 & 11.5 & $\mathrm{~T}$ & $\mathrm{~T}$ \\
\hline After cleaning & & 88.15 & 98.83 & 99.99 & 99.99 \\
\hline The eficasity scale of cleaning & & &
\end{tabular}

Tab. 3.Sample nr.2.

\begin{tabular}{|l|l|l|l|l|l|}
\hline Sample 2 (mg /l) \\
\hline Wastewater & $\mathrm{pH}$ & $\mathrm{Pb}$ & $\mathrm{Zn}$ & $\mathrm{Cu}$ & $\mathrm{Cd}$ \\
\hline Para pastrimit Before cleaning & 1.9 & 0.9 & 904 & 2.6 & 1.7 \\
\hline Pas pastrimit After cleaning & 8 & 0.5 & 305 & 1.4 & 1.2 \\
\hline Pas pastrimit After cleaning & 9 & 0.24 & 110 & 0.78 & 0.6 \\
\hline Pas pastrimit After cleaning & 10.5 & 0.12 & 23.3 & 0.34 & 0.15 \\
\hline The eficasity scale of cleaning & & 86.66 & 97.42 & 86.92 & 91.17 \\
\hline
\end{tabular}


Book of Proceedings

International Conference on Mechatronics, Sciences in Energy Efficiency Engineering,

System Engineering and Robotics

Tab. 4. Sample nr.3.

\begin{tabular}{|l|l|l|l|l|l|}
\hline Mostra 3 (mg /l) & $\mathrm{pH}$ & $\mathrm{Pb}$ & $\mathrm{Zn}$ & $\mathrm{Cu}$ & $\mathrm{Cd}$ \\
\hline Wastewater & 1.5 & 1.9 & 1250 & 1.34 & 2.7 \\
\hline Before cleaning & 8 & 0.4 & 340 & 0.7 & 0.23 \\
\hline After cleaning & 9 & 0.5 & 85 & $\mathrm{~T}$ & $\mathrm{~T}$ \\
\hline After cleaning & 10.5 & 0.03 & 9.6 & $\mathrm{~T}$ & $\mathrm{~T}$ \\
\hline After cleaning & & 98.42 & 99.23 & 99.99 & 99.99 \\
\hline The eficasity scale of cleaning & &
\end{tabular}

\section{Discussion of results}

Based on the results obtained reach the conclusion that:

- Precipitation as full of havy metals must be carried out in the $\mathrm{pH}$ values of 10.5

-For larger quantities slaked lime added to the $\mathrm{pH}$ increase and this increases the degree of purification, the $\mathrm{pH}$ of 10.5 to 12.5 , because with increasing $\mathrm{pH}$ value, zinc passes at zincate.

-At $\mathrm{pH}$ values from 10.5 to 12.5 by flow $99.99 \%$ efficiency of the impurities removed heavy metals such as $\mathrm{Zn}, \mathrm{Cu}$ and $\mathrm{Cd}$.

-In the same $\mathrm{pH}$ conditions achieved clearance rate of $87 \% \mathrm{~Pb}$ deviation of $\mathrm{Pb}$ sçarohet the fact that the optimum $\mathrm{pH}$ values for the removal of $\mathrm{Pb}$ ranging from 8-10.5. Above these values come back up in the form of $2 \mathrm{PbCO} 3 \mathrm{~Pb}(\mathrm{OH}) 2$, and with this the increase of the concentration of ions present.

-For removing $\mathrm{Cu}$ need $\mathrm{pH}=8$, while the removal of $\mathrm{Cd}$ required $\mathrm{pH}$ value of about 9 . While the limit for $\mathrm{Pb}$ reached by difficult.

Limits concentration of heavy metals which may precipitation in the ranges allowed, regardless processing with slaked lime, are quite variable and depend on the nature same pollution.

With the development of the reaction of $\mathrm{Pb}, \mathrm{Fe}$ and $\mathrm{Cu}$ through processing with slaked lime, for a short time come to preceptation in the form of hydroxide, and for $\mathrm{Zn}$ and $\mathrm{Cd}$ need a longer time.

Research has proven that during the processing of industrial wastewater with slaked lime, precipitation process of heavy metals is effective for the $\mathrm{pH}$ value of 10.2 .

This applies for $\mathrm{Cu}, \mathrm{Zn}, \mathrm{Fe}$ and $\mathrm{Cd}$, while for $\mathrm{Pb}$ to $\mathrm{pH}$ values of 10.5, come to his melting with zinc and as a result of the reaction of $\mathrm{Pb}$ content exceeded the initial polluted water.

This shows that for determining the degree of purification of industrial wastewater should be in mind keeping the $\mathrm{pH}$ value in the ranges allow for an efficient precipitation to each heavy metal.

\section{RESUME}

With the process neutralization with slaked lime to achieve that the majority of metal ions preceptiation in the form of hydroxide.

The efficiency of heavy metals preceptiation depending on by $\mathrm{pH}$ value with milk lime, as follows: $\mathrm{Pb}$ $=65-83 \% ; \mathrm{Zn}=93-99 \% ; \mathrm{Cu}=65-83 \%$ and $\mathrm{Cd}=95-99 \%$, so it is within the allowed limits and after preparing enabled the issuance of industrial wastewater according to the legal rules for the protection of water. 
The Neutralization of Water Polution

In cases when have to deal with increased alkaline during the process of neutralization, then we have to add acid melting or an amount of water industrial waste, so that the $\mathrm{pH}$ value to correspondence with the conditions of the working environment, as defined according to the rules of law .

In cases when have the average values of heavy metals in industrial waste water, then needed value is $\mathrm{pH}=10.5$, while in cases when have with overload process, then needed value is $\mathrm{pH}=12.5$

\section{References:}

1. Cheremisinoff Nicholas R.Hanbook of water and wastewater treatment Technologies, Woburn, 2002.

2. Institute of lead and zinc in ,Trepça' complex, Mitrovica, 1987.

3. Preparing water, Technological and Metalurgical faculty of Belgrad, 1994.

4. Standard Methods for the Examination of Water and Wastewater, 20/th edition, APHA, AWWA, Washington 2000.

5. Patterson J.W. Wastewater treatment Technology, Ann Arbour Science, Michigan, 1975.

6. World Health Organisation-Environmental Health Criteria Series,EHC 228.Principles and Methods for the Assessment of risk from Essential Trace Elements.WHO Geneva. http://wwww.inchem.org(document/ehc/ehc $228 \mathrm{htm}$ ) . 